This item was submitted to Loughborough's Research Repository by the author.

Items in Figshare are protected by copyright, with all rights reserved, unless otherwise indicated.

\title{
The role of marketing resources in radical innovation activity: antecedents and payoffs
}

\section{PLEASE CITE THE PUBLISHED VERSION}

http://dx.doi.org/10.1111/jpim.12285

\section{PUBLISHER}

(C) Product Development \& Management Association. Published by Wiley.

\section{VERSION}

AM (Accepted Manuscript)

\section{PUBLISHER STATEMENT}

This work is made available according to the conditions of the Creative Commons Attribution-NonCommercialNoDerivatives 4.0 International (CC BY-NC-ND 4.0) licence. Full details of this licence are available at: https://creativecommons.org/licenses/by-nc-nd/4.0/

\section{LICENCE}

CC BY-NC-ND 4.0

\section{REPOSITORY RECORD}

Kyriakopoulos, Kyriakos, Mathew Hughes, and Paul Hughes. 2015. "The Role of Marketing Resources in Radical Innovation Activity: Antecedents and Payoffs". Loughborough University. https://hdl.handle.net/2134/24330. 


\title{
The Role of Marketing Resources in Radical Innovation Activity: Antecedents and Payoffs
}

\author{
Kyriakos Kyriakopoulos (corresponding author) \\ ALBA Graduate Business School \\ at The American College of Greece \\ Xenias Str. 6-8, \\ 115 28, Athens, \\ Greece \\ Tel: +30 (2) 10 8964531-8 (2225) \\ Fax: +302108962139 \\ E-mail: kkyriako@alba.edu.gr \\ Mathew Hughes \\ Reader in Entrepreneurial Management \\ Durham University Business School \\ Durham University \\ Mill Hill Lane \\ Durham DH1 3LB \\ United Kingdom \\ Tel: +44 (0) 1913345906 \\ Email: Mat.Hughes@durham.ac.uk

\section{Paul Hughes} \\ Senior Lecturer in Strategy \\ Durham University Business School \\ Durham University \\ Mill Hill Lane \\ Durham DH1 3LB \\ United Kingdom \\ Tel: +44 (0) 1913345393 \\ Email: Paul.Hughes@durham.ac.uk
}




\section{Author Bios}

Kyriakos Kyriakopoulos is Associate Professor of Strategy \& Marketing at ALBA Graduate Business School at The American College of Greece. His research interest revolve around innovation, market learning, improvisation, and marketing assets \& capabilities. His research has been published in leading international journals such as the Journal of Marketing, Organization Studies, International Journal of Research in Marketing, Journal of Management Studies, and Agribusiness. Currently, he serves as Associate Dean for Academic Programs.

Mathew Hughes is Reader in Entrepreneurial Management at Durham University Business School. His research interests include entrepreneurial orientation, innovation ambidexterity, entrepreneurial management, organizational learning, and social capital. His work is published in several respected journals including Strategic Entrepreneurship Journal, British Journal of Management, Journal of Business Research, and Industrial Marketing Management. He is also a currently serving member of the editorial board for Journal of Management Studies.

Paul Hughes is Senior Lecturer in Strategy at Durham University Business School. Research interests include strategic planning and improvisation, strategic resource use, and strategy failure. His work is published in several respected journals including Strategic Entrepreneurship Journal, Public Administration, British Journal of Management, European Journal of Marketing, Journal of Business Research, and Group \& Organization Management. 


\title{
The Role of Marketing Resources in Radical Innovation Activity: Antecedents and Payoffs
}

\begin{abstract}
While radical product innovations represent significant engines of firm growth, questions remain over whether marketing helps or hurts (1) a firm's radical product innovation activity and (2) its rewards from radical product innovation activity. By attaching an attention-based view of the firm to a market-based assets view of marketing, this article examine the role of three marketing resources - market knowledge, reputation, and relational resources — on radical innovation activity. Our conceptual framework posits differentiated effects among marketing resources as antecedents of radical innovation activity and as moderators of its impact on firms' financial performance. Using a survey of a broad set of high-tech B2B firms to test hypotheses, it is found that firms with strong relational resources enjoy a higher propensity for, and stronger financial rewards from, radical innovation activity. Reputational resources come with a trade-off as they hurt the incidence of radical innovation but enhance its financial rewards. However, market knowledge resources appear to hurt both radical innovation activity and its financial rewards. Our results point to the multi-faceted role of marketing in radical innovation activity, which is unlikely to come with a single benefit or liability as prior work often posits. Rather, our research heightens the alertness of managers to assess their firms' marketing strength as a bundle of stocks of several marketing resources. Managers must understand the distinct benefits and drawbacks of each resource in developing and launching radical innovations. Our research underscores the differentiated value of marketing in radical innovation activity in B2B high-tech contrary to the entrenched idea of a limited or even stifling role of marketing in this context.
\end{abstract}

\section{Practitioner Points}

- Managers must be acutely aware of the distinct benefits and drawbacks of marketing resources — market knowledge, relational, and reputational resources — in developing and commercializing radical innovations in B2B high-tech industries.

- The results caution that market knowledge resources in excess can bind the firm to its present markets. Diminishing returns from this resource suggests that managers should be conscious of its attention-guiding properties, and consider what exploratory activities are needed to ensure a wider spectrum of knowledge enters the firm and is acted on.

- The positive effects of relational resources on both radical innovation activity and its financial reward suggest managers should avoid self-reliance and build relational resources with customers, suppliers, and distribution channels. Managers will need to invest time to build the requisite social capital so that this resource becomes valuable, rare and capable of exposing the firm to new knowledge and resources of value to radical innovation activity.

- While reputational resources can inhibit the willingness for radical innovation activity, they increase its payoffs. Managers, therefore, must balance the need to cultivate and protect corporate image against its potential to subvert radical innovation activity. 


\section{Introduction}

Whether marketing helps firms generate and benefit from radical innovation is a crucial issue for marketing and strategy scholars (e.g., Slater, Mohr, and Sengupta 2014; Tellis, Prabhu, and Chandy 2009; Utterback 1994; Zhou, Yim, and Tse 2005) given the potential of radical innovation to transform the fortunes of firms and entire industries for better or worse (Sorecsu and Spanjol 2008; Tellis et al. 2009). Two contrasting views on the role of marketing are present in the literature. Work outside marketing paints a bleak picture as marketing resources built over time color managers’ perceptions of radical innovations. For example, close customer relations (Christensen and Bower 1996; Utterback 1994) and corporate reputation increase managers’ risk aversion (Cooper and Smith 1992; Levinthal and Myatt 1994) and fuel resistance to cannibalize current products and technologies (Hamel and Prahalad 1994). Eventually, blinded by their knowledge of current markets and products, incumbents become biased against emerging fields thereby depressing radical innovation (Tripsas and Gavetti 2000).

In contrast to this gloomy view, marketing science offers a more nuanced perspective of the role of marketing in radical innovation (Atuahene-Gima 2005; Baker and Sinkula 2005; Evanschitzky et al. 2012). A key conclusion is that a broader focus of market orientation to include attention to future needs and trends promotes breakthrough innovations in firms (Zhou et al. 2005) because it fosters the very willingness to cannibalize existing products in high-tech industries that is so often absent (Chandy and Tellis 1998; Lindgren and O’Connor 2011). Concurrent research in marketing and strategy has also shown that marketing helps firms to exploit their innovations profitably (Chandy and Tellis 2000; Danneels 2004; Evanschitzky et al. 2012; Tripsas 1997). Firms with strong brand and channel resources, for example, are more likely to benefit from their radical innovations (e.g., Pleatsikas and Teece 2001; Teece 1986).

What explains these contrasting views of the role of marketing in radical innovation? These long-standing conflicts may well be due to the lack of a unifying framework of marketing's role in 
radical innovation activity. As one remedy, this article refers to the marketing resources literature to consider the role of marketing resources in driving and profiting from radical innovation, and the attention-based view of the firm is relied on to understand why marketing resources cause entirely different effects on radical innovation activity than hoped. From the works of Srivastava Shervani, and Fahey (1998), Srivastava, Fahey and Christensen (2001), and Morgan (2012) that set out the three main marketing resources available to a firm—-market knowledge, reputational, and relational resources - this article examines how a firm's stock of marketing resources affect the incidence of radical innovation activity, and how these marketing resources affect the extent to which a firm benefits financially from this activity. For this research, radical innovation is defined as the propensity of a firm to introduce radically new products (Tellis et al. 2009).

Grounded in the resource-based view (RBV) of competitive advantage (Barney 1991), firm-specific, hard-to-imitate marketing resources are crucial to visioning new markets (Reid and de Brentani 2010, 2012) and to developing new products successfully (Evanschitzky et al. 2012; Henard and Szymanski 2001). But through the lens of the attention-based view (Ocasio 1997), these same resources can channel the attention of managers in ways that compromise radical innovation activity. Intellectual resources can be tyrannized by the served market (Hamel and Prahalad 1994), reputation can raise an unwillingness to risk new products that might endanger the brand (Cooper and Smith 1992), while relationships can expose firms to new information and resources that change their system of constraints (Hughes and Perrons 2011).

Our work offers three key contributions. First, this work contributes to radical innovation research a first study to parse out the effects of various marketing resources both as inputs into radical innovation activity and as moderators of its financial success within the same study. Prior work examines the role of marketing either as an antecedent of radical innovation (Atuahene-Gima 2005; Zhou et al. 2005) or moderator of its impact on firm performance (Sorescu, Chandy, and Prabhu 2003). Our focus extends prior work that acknowledges firm resources as important in 
visioning new markets (Reid and de Brentani 2010, 2012) and developing new products (Evanschitzky et al. 2012; Henard and Szymanski 2001), but has also evidenced how the resources held by a firm can make it complacent, curbing its ability to radically innovate- the 'liability-ofwealth’ hypothesis (Debruyne, Frambach, and Moenaert 2010). By connecting these research streams to the attention-based view of the firm, this work contributes to this emerging stream (Joseph and Ocasio 2012; Kaplan 2008; Ocasio 1997; Tripsas and Gavetti 2000): from a resource perspective, what selectively focuses the attention of managers and why, and what are the business implications of attention being channeled in particular ways? Radical innovation activity offers a prime context in which to study the effects of managerial attention being channeled in unforeseen ways and resources offer a way to understand why attention might be channeled in particular ways.

Second, in extending the work on direct effects of different marketing resources in a single study (e.g., Krasnikov and Jayachandran 2008; Morgan 2012; Morgan, Slotegraaf, and Vorhies 2009), an integrated view is provided and one that speaks to radical innovation activity as a precursor to company performance. It is shown that accumulated marketing resources do not just affect competitive advantage directly but how they affect the incidence of radical innovation and its returns. Focusing on radical innovation, hence, extends the direct effects view of marketing resources on company performance (e.g., Morgan et al. 2009).

Third, prior work has relied on sectors such as semiconductors, pharma, or computer manufacturing but, "it is always perilous to speculate about the applicability of results from one industry to another” (Sorescu et al. 2003, p.97). To examine our theory, a wide pool of high-tech B2B industries is relied upon. These industries, ranging from medical instruments, chemicals to electronics, feature R\&D intensity, have manufacturing activity, and serve business customers. While high-tech B2B firms have historically been product- and technology-focused (Aaker and Jacobson 2001), changes in markets have led to investments in more complex marketing resources 
to develop better-targeted initiatives to customers (Ericksen, Jullens, and Kataria 2009). Our results address the growing call for a better understanding of marketing's contribution to B2B innovation (Griffin et al. 2013); a call that stands against a legacy in which marketing has been marginalized (Workman 1993) and seen as unwarranted (Aaker and Jacobson 2001).

\section{Theoretical Framework}

\section{Radical Innovation Activity}

Radical product innovation (radical innovation hereon) is defined as the propensity of a firm to introduce new products with a substantially different or new technology that offer higher customer benefits over previous products in the industry (Chandy and Tellis 1998 2000; Gatignon et al. 2002; Govindarajan, Kopalle, and Danneels 2011; O’Connor 1998; cf. Bower and Christensen 1995). Herein, radical innovation is treated as a firm or unit activity, consistent with recent work in this field (e.g., Tellis et al. 2009; Zhou et al. 2005).

Radical innovations tend to produce large advancements in the price/performance frontier and depart from the current technological trajectory while incremental innovations typically only improve the established technological trajectory (e.g., line extensions, me-too products), involving relatively minor changes in technology and providing relatively low incremental customer benefits per dollar spent (Chandy and Tellis 1998). Though radical innovation can be further classified as disruptive or sustaining (Bower and Christensen 1995), our definition of a radical product innovation centers on a new product that is based on a substantially new technology, and fulfills key customer needs much better than the established technology (Chandy and Tellis 1998; Ettlie, Bridges, and O’Keefe 1984; Slater et al. 2014; Tellis et al. 2009). ${ }^{\text {i }}$

Radical innovations hold great promise for firm performance because relative to incremental innovation, radical innovations can offer unprecedented customer benefits, substantial cost reductions, and renew firms (Slater et al. 2014; Tellis et al. 2009). Radical innovation activity 
can then yield important returns to firm performance, including improved financial outcomes, improved cash flows, and higher firm valuations by stock markets and investors (Evanschitzky et al. 2012; Sood and Tellis 2009). Radical innovations also tend to generate more positive firm performance outcomes than incremental innovations (Rubera and Kirca 2012). Nevertheless, despite such promise, the success rates of new products and their financial contributions remain modest at best (Barczak, Griffin, and Kahn 2009).

Much of the blame has been directed at the failure of studies to sufficiently discriminate between antecedents relevant to radical innovation over and above incremental innovation (Ettlie et al. 1984; Slater et al. 2014). In a comprehensive literature review, Slater et al. (2014) posit senior leadership, organizational culture, organizational architecture, the radical product innovation development process, and the product launch strategy as components of a 'radical product innovation capability’. Moreover, a recent meta-analysis of factors predicting new product success by Evanschitzky et al. (2012) reported on the effects of product, strategy, process, marketplace, and organizational characteristics on the firm performance effects of radical innovation. However, these two reviews raise a tension surrounding how radical innovation might be conceptualized.

Slater et al. (2014) see radical innovations as a capability, defining it as, "the ability to successfully develop and commercialize radical product innovations” (p.553). Radical innovation is not examined as a capability in this present study; rather the incidence of radical innovation by way of a firm's propensity to introduce new products is examined, consistent with Chandy and Tellis (1998) among others, treating it as an activity instead. This is done so because Slater et al. (2014, p.553) specify that, "a radical product innovation capability provides for the development and commercialization of products/services that offer unprecedented performance benefits, substantial cost reductions, or the ability to create new businesses”. 
Our approach leaves open judgments about the quantity of radical innovations produced, whether the firm lags behind competitors in introducing such innovations, its aggression towards innovating, and the financial payoffs of those radical innovations (Chandy and Tellis 1998; Tellis et al. 2009). This also allows us to consider the resource implications of radical innovation activity and how the nature and level of a firm's marketing resources influence the incidence and success of its radical innovation activity. This is timely because in both literature reviews, the relative body of knowledge on how different types of resources and their stocks within firms affect radical product innovation activity is thin, despite an acceptance that radical innovation activity is resource intensive (Barczak et al. 2009; Slater et al. 2014).

\section{Resources and radical innovation activity}

The resource intensity of radical innovation activity is driven by the great technical and market uncertainties associated with it. It is in explaining how firms combat these uncertainties that organizational resources have emerged as important aspects of radical innovation (Lynn Morone, and Paulson 1996; McDermott and O’Connor 2002; O’Connor and Rice 2013). In this debate, issues of firm dominance, size, investments, and incumbency affect the availability and deployment of resources towards radical innovation. Implicit in this discourse is that types of resources direct the attention of managers. Innovation activity requires an allocation of resources, but the activities resources are currently tied to also guide and inform their meaning and the allocation process itself (Garcia 2005). It is in this tension that the ambivalent role of marketing in radical product innovation emerges.

Evidence for adopting an attention-based view to understand radical innovation activity given a stock of resources is high. For example, dominant firms are portrayed as risk-averse, inert, and unwilling to cannibalize their products and investments owing to the unique resource investments tied in them (Chandy and Tellis 1998; Christensen and Bower 1996; Tripsas 1997); biases towards current customers or 'the tyranny of the served market' (Hamel and Prahalad 1994) 
also favor attention to be directed towards investments in incremental innovation against breakthrough projects; and recent works have found evidence that large stocks of technological, marketing, or financial resources can cause complacency among managers, leading firms to overpredict their ability to respond to a competitor's new product introduction while under-predicting its likely success (Debruyne et al. 2010). Other works point to the complexity of modern innovations as requiring firms to hold strong marketing resources to drive and exploit innovations profitably through greater understanding of customers and markets (Chandy and Tellis 2000; Danneels 2004; Griffin et al. 2013; Pleatsikas and Teece 2001; Teece 1986; Tripsas 1997). Recent work on market visioning by Reid and de Brentani (2012) also suggests that greater resource availability positively impact the relationship between a market visioning competence and the emergence of a market vision-a complex and nebulous image of a future product-market. However, Reid and de Brentani (2012) only presented arguments for the availability of resources. In this article it is suggested that the availability of particular types of resource might drive attention to or away from radical innovation activity in this respect.

The attention-based view of the firm (Joseph and Ocasio 2012; Kaplan 2008; Ocasio 1997) is therefore drawn upon to theorize how and why different bundles of resources and their stocks may generate different effects on the incidence of radical innovation and its payoffs. It is proposed that firms' resource stocks can direct the attention of its managers towards particular activities that 'sell' an agenda to top management that then allocates their attention towards particular actions and activities over others (Dutton and Ashford 1993). Based on the attention-based view, existing stocks of resources channel the actions of employees and managers towards activities they are familiar with (Ocasio 1997), and to which those resources originated from or are predominantly tied to or connected with. For example, deep pockets of marketing resources, such as extensive knowledge of familiar markets and historical brand resources, can direct attention to ongoing products such that the uncertainty of change reduces the impetus for activities that are new or 
novel in nature (March 1991). As innovations compete for resources and management attention (Garcia 2005), radical innovations can get left behind. The next section introduces the three core marketing resources that have the potential to affect radical innovation and examines the role of attention therein.

\section{Marketing Resources}

Marketing resources are theorized in the market-based assets view of marketing, which grew out of the RBV (Morgan 2012; Srivastava et al. 1998, 2001). Srivastava et al. (1998, p.4) define an asset or resource as, "any physical, organizational, or human attribute that enables the firm to generate and implement strategies that improve its efficiency and effectiveness in the marketplace”. The RBV treats a firm as a unique collection of tangible and intangible resources, where the heterogeneity and immobility of resource stocks are key sources of competitive advantage (Barney 1991). Resources that exhibit value, rarity, inimitability, and nonsubstitutability can enable a firm to craft innovation (Prahalad and Hamel 1990). Marketing resources are valuable because they are rare, imperfectly imitable, not easily substitutable, and are convertible in that they can be used to pursue opportunities or neutralize threats (e.g., by contributing to radical innovation activity) (Srivastava et al. 1998, 2001). They are also unique to each firm because they are born from its past marketing activities, actions, and investments.

Marketing resources are particularly relevant to innovation activity. Evanschitzky et al.'s (2012) meta-analysis of the success factors of product innovation reveals that marketing resources hold particular potential for product innovation activity in that "in addition to nonsubstitution of assets, the employment of these assets and the transformation of these assets into productive skills and activities are entirely of separate essences; and both [are] tacitly and practically nonsubstitutable regardless of [the] degree of integration” (p.30), consistent with other research (e.g., Moorman and Slotgraaf 1999). Evanschitzky et al. (2012) concluded that a theoretical 
reconsideration is needed to move away from an examination of total asset size to consider the segmented forms a resource might take.

Two key parameters are noticeable: first, an aggregate evaluation of the marketing resources held by a firm is no longer sufficient (in contrast to previous studies, e.g., Moorman and Slotegraaf 1999; Song et al. 2005; Sorescu et al. 2003); second, distinct types of marketing resources may affect radical innovation activity in a differentiated way. This is consistent with a view of radical innovation activity as dependent on the allocation of resources from senior managers. The attention-based view of the firm (Ocasio 1997) allows us to theorize the effects of types of marketing resources and their stocks on radical innovation activity.

Research conceptualizing market-based assets converges on three key marketing resources: intellectual, relational, and reputational assets (Morgan 2012; Srivastava et al. 1998). These arise idiosyncratically from the commingling of the firm with entities in its external environment and the unique investments it makes over time (Srivastava et al. 1998). The idiosyncratic manner by which these resources form render them valuable, rare, inimitable, and non-substitutable, and can potentially offer competitive advantages (Morgan 2012; Srivastava et al. 1998) through unique contributions to innovation activity (Evanschitzky et al. 2012).

Intellectual resources characterize the market knowledge resources of the firm capturing its stock of knowledge about customers, competitors, channel partners, and its experience, information, and intelligence about its marketplace (Jaworski and Kohli 1993; Morgan, Vorhies, and Schlegelmilch 2006; Srivastava et al. 1998). The innovation potential of market knowledge resources can be understood as an attention guiding mechanism (Garcia 2005; Ocasio 1997). Market knowledge resources guides radical product definition (Berchicci and Tucci 2010) and market visioning for their radical innovation activity (Reid and de Brentani 2010, 2012), and shapes the ability of individuals in the firm to link existing, new, or emerging technologies to new market opportunities relevant to radical innovation activity (O’Connor and Veryzer 2001; Song 
and Montoya-Weiss 1998). However, large stocks of market knowledge resources might not develop the sort of market visions conducive to radical innovation because they are grounded in the past experiences and knowledge of the firm in its market(s). Instead they prioritize individuals with information about existing markets that compromises novelty and cause convergence around incremental innovation activity (Garcia 2005; Reid and de Brentani 2010).

Reputational resources form from a firm's corporate image and name in its market, the value of which is shaped by the awareness, strength, distinctiveness, and appeal of its corporate image relative to its competitors (Brown and Dacin 1997; Morgan 2012; Morgan et al. 2006). Reputational resources in the form of corporate image can enhance product attractiveness to customers, generate positive product responses, and shape positive customer evaluations of radically innovative new products (Brown and Dacin 1997) capable of accelerating customer acquisition (Stahl et al. 2012) and financial gain (Aaker 2004) from a new radical innovation. However, their effects as input into radical innovation activity are less clear. From an attentionbased view, strong reputational resources direct attention towards image preservation and can discourage radical innovation activity that places it at risk of harm (Chandy and Tellis 1998).

Relational resources are conceptualized as valuable bonds a firm holds between itself and its channel partners and customers in terms of strength, quality, duration, closeness, and quantity (Srivastava et al. 1998). They reflect a firm’s social capital (Noordhoff et al. 2011). Relational resources are potentially valuable for a firm's radical product innovation activity because they can expose the firm to new technologies, expose it to novel knowledge, and encourage interfirm innovation activity (Cui and O’Connor 2012; Hughes and Perrons 2011). In this way, relational resources can direct the attention of firms to new information, data, and knowledge it would otherwise not be exposed to. Thus, relational resources are potentially valuable to radical innovation activity as partners can pool complementary resources and intellectual capital to scale radical innovation activities beyond the limitations of a firm’s own resource base. Relational 
resources therefore hold the potential to transcend the system of constraints held by any one firm in increasing radical innovation activity and securing payoffs from it.

After reviewing the foundational elements of our theory, attention is now given to our key focus: how different marketing resources affect (1) the propensity of a firm to introduce radical innovations and (2) the financial reward from radical innovations (see Figure 1).

[Insert Figure 1 here]

\section{Marketing Resources as Antecedents of Radical Innovation Activity}

The market knowledge resources held by a firm represent the stock of past knowledge, experience, and intelligence a firm possesses about its market(s), including "the emerging and potential state of market conditions and the entities in it”, such as competitors, customers, and channels members (Srivastava et al. 1998, p. 5). Consistent with an attention-based view of the firm, market knowledge resources shape the decisions of managers about radical product definition and the scope of the firm's radical innovation activity (Berchicci and Tucci 2010). Prior market experiences and knowledge also drive allocation decisions (Garcia 2005). Strong market knowledge resources are grounded in the past. While this increases the absorptive capacity of the firm to interpret and assimilate 'new' knowledge (Cohen and Levinthal 1990), it can also bias that interpretation leading to less novel, radical actions being taken (Autio, Sapienza, and Almeida 2000) in favor of tweaking existing products (Garcia 2005).

Theoretically, contrasting views of how prior stocks of market knowledge can affect radical innovation emerge. One view purports that innovation rarely relies exclusively on new knowledge and innovation activity is therefore a function of recombining existing knowledge in novel ways (Prabhu, Chandy, and Ellis 2005). Prior knowledge informs the absorption and use of new knowledge. Accordingly, customer and competitive intelligence help firms address customer needs and anticipate future ones (Atuahene-Gima 2005; Slater and Narver 1999). 
On the other hand, large stocks of market knowledge resources are associated with rigid behavior and entrenched mental maps (Day 1994) that direct attention to information that suits established priorities (Ocasio 1997). These entrenched cognitive schemata can make firms myopic to new opportunities (Autio et al. 2000) and lead managers to pursue incremental innovations rather than radical ones (Tripsas and Gavetti 2000). A radical innovation that creates either a new line of business or a new product form relies on very different market knowledge to that informing an incremental innovation, largely because customers are not able to describe their requirements for a product that involves entirely new markets or applications (O’Connor 1998). Thus, high stocks of market knowledge resources can blind firms and stifle their radical innovation activity while relatively modest stocks puts less constraints on the interpretation and use of newer knowledge encountered in the world (Autio et al. 2000). In excess then, these stocks will prevent firms from envisioning new futures so important to radical innovation activity (Reid and De Brentani 2010).

Taken together it is suggested that stocks of market knowledge resources have an inverted U-shaped effect on radical innovation activity (Kyriakopoulos and de Ruyter 2004). Too much prior market knowledge can impede creative thinking and filter out market changes. Low levels of it, however, can make the innovation process inefficient and unstructured. Instead, moderate levels of market knowledge resources promote the highest levels of radical innovation because they endow a firm with sufficient absorptive capacity without falling prey to inertial forces. Thus:

H1: There is an inverted U-shaped relationship between market knowledge resources and radical innovation in which intermediate levels of marketing knowledge produce the highest level of radical product innovation activity.

Reputation is expected to have a negative impact on radical innovation activity. As radical innovations tend to displace existing products, reputable firms face increased risks from abandoning proven products, established markets positions, and technologies (Levinthal and Myatt 1994). Even if firms are risk tolerant, their tenacity will be tested as new technologies tend to be 
suboptimal in the beginning of the product life cycle (Utterback 1994) and might not speak clearly to customer needs (Bower and Christensen 1995), even if designed to do so (Chandy and Tellis 1998), because the vision underpinning a radical innovation is often obtuse to the customer. Cooper and Smith, in accounting for the unwillingness of incumbent firms to invest in new radical technologies, suggest that no matter how well conceived, "the new product's early imperfections could tarnish the firm's reputation, as such, there was a reluctance to make a full commitment until the product was ‘proven'” (1992, p.63).

Seen through the lens of the attention-based view, strong reputation resources in the form of a strong, established, corporate image can regulate managers' behaviors against taking actions that carry uncertain effects on powerful, iconic organizational assets such as reputation (Ocasio 1997). 'Selling' a radical innovation to top management when a risk (even if only symbolic) exists to dissolving, diluting, or damaging the firm's corporate image with key stakeholders becomes doubly difficult (Dutton and Ashford 1993). Research on reputation echoes this concern: "good reputations lead to increased temporal stability in the short run but may induce some rigidity that may harm superior-performing firms in the longer term” (Roberts and Dowling 2002, p.1091). In a B2B firm (and less in B2C that often adopt a multi-brand approach), its product reputation is tied largely to its corporate reputation and this dyad is bidirectional. A radical innovation that turns out to be poor damages not only the product but also the corporate image. Reputational resources then direct managers' attention towards more sustaining incremental innovation at the expense of radical innovation activity as the risks to corporate image are far lower.

Elements of this problem surface in Bower and Christensen's (1995) famous example of the hard-disk-drive industry: leaders stumbled at each point of radical, disruptive change not because the technology was inaccessible to them but because they had entrenched views of their product and corporate identity. The slow speed of leaders versus lesser-known firms to introduce new architectures was in stark contrast to their timely launches of sustaining technologies. 
Radical innovations can also steal sales from existing lines (Kerin Harvey, and Rothe 1978) and can reduce existing brand differentiation, increasing uncertainty in price and sales by rendering existing brands closer substitutes than before (van Heerde, Mela, and Manchanda 2004). These actions are ultimately capable of affecting corporate image in unpredictable ways that further divert the attention of managers away from radical innovation activity. Managers then direct their attention towards maintaining the heritage of corporate image, stifling motivation for radical innovation as shown in the mutual fund processing industry (Levinthal and Myatt 1994). Thus:

H2: There is a negative relationship between reputational resources and radical product innovation activity.

Relational resources can increase radical innovation activity for several reasons. First, linkages with supply chain partners expose the firm to emerging technologies and new perspectives it could otherwise be blind to in its daily operations (Hughes and Perrons 2011). Intel, for example, relies on its web of relationships with its customers to glean insights on new families of chips (D’Aveni 1995). Relational resources achieve this result by facilitating the exchange of two types of information among partners. Close partners will be less concerned with the loss of proprietary information such as customer or technology information. In conditions of reciprocity and trust facilitated by strong existing relationships, fears of partner opportunism subside to ease transfer of sensitive information (Heide, Wathne, and Rokkan 2007). Also, close relationships facilitate the exchange of complex, more tacit information as embedded partners develop relationship-specific heuristics that help transfer ‘sticky’ knowledge (Noordhoff et al. 2011). Access to proprietary and tacit knowledge enables greater exploratory activity (Grant and BadenFuller 2004) which increases the scope for radical innovation activity to take place.

The firm's body of social capital rests within its existing ties and, when strong, can unlock access to knowledge and resources beyond its control capable of changing the system of 
constraints that affect the firm. This enables managers to direct attention to new product activity. By enabling a firm to combine its own resources with those available through its relationships, the firm can generate a larger number of new innovations than it could alone (Rothaermel 2001). As firms turn to external knowledge sources in an effort to develop activities more divergent from its existing set, they increase their ability to undertake radical innovation (Cui and O’Connor 2012; Emden et al. 2006). Studies in many industries show that innovation activities are increasingly a function of relationships with supply chain partners (Powell 1998) and suppliers (Hughes and Perrons 2011). Therefore:

H3: There is a positive relationship between relational resources and radical product innovation activity.

\section{Marketing Resources as Moderators of the Value of Radical Innovation}

In addition to their role in fuelling radical innovation activity, marketing resources can affect the impact of this activity on financial performance. Our focus builds on the well-established view that innovators do not automatically benefit unless they possess complementary assets (e.g., Sorescu et al. 2003; Teece 1986; Tripsas 1997). Other research, however, claims that such firms might also be overconfident and blinded in deploying their marketing resources in support of radical innovations (Debruyne et al. 2010). This work extend these equivocal views by exploring the moderating role of each resource on the innovation-performance relationship.

It is expected that market knowledge resources will negatively moderate the contribution of radical innovation activity to firm financial performance. Prior knowledge can lead innovators to adopt the wrong business model when launching an innovation. Prior knowledge consists of heuristics and entrenched mental models (Day 1994) that can be detrimental when trying to appropriate value from radical innovation activity. Knowledge is developed through path dependent learning processes (Henderson and Cockburn 1994) that are largely driven by the ongoing product-market activities of the firm. 
In the very different and changing market landscape generated by radical innovation activity, there is a danger of firms applying past recipes to cope with the uncertainty of taking radical innovation to market, which is unlikely to be optimal (Moorman and Miner 1997). Extensive market knowledge resources then guide the attention of aspiring innovators to exploit 'tried-and-tested' models. As innovators rely on tacitly held knowledge they become blind to nonstandard customer needs or competitive reactions (Leonard-Barton 1992). Therefore, their ability to effectively commercialize radical innovation activity is compromised by the amount of knowledge developed over the years.

H4: The greater the market knowledge resources, the lower the likelihood that radical product innovation activity will promote the financial performance of the firm.

While $\mathrm{H}_{2}$ predicts that firms with strong reputational resources will stumble to radically innovate, these same resources might help increase the firm financial performance from it as predicted in $\mathrm{H}_{5}$. Strong corporate images can have sizable effects when extended to the commercialization of new innovations because of the positive customer attitudes, information schemas, and expectations built through historical marketing communications and held within perceptions of a positive corporate image (Capron and Hulland 1999). Such knowledge held inside the minds of customers can reduce the uncertainty associated with launching radical product innovations (Brown and Dacin 1997). Without reputational resources, a firm would have to spend considerable dollars developing awareness and image for its radical innovation. Deploying historical reputational resources thereby help firms commercialize and gain from radical innovation activity (Aaker 2004).

To explain further our argument, strong corporate image signals that the organization is held in high regard (Weiss Anderson, and MacInnis 1999). Such reputation offers customers confidence when faced with little other information to make a rational purchase decision (because of the newness of the products technology and features held within the radical innovation). This 
positive preconception of what a product may offer (facsimiled from the positive corporate image) does not assuage management concern about the damage a radical innovation could do to corporate image, but as managerial attention now shifts to commercialization, the ability of reputational resources to signal values and qualities to customers render them useful in the commercialization of radical innovations, which typically have few, if any, direct market referents (Aaker and Jacobson 2001). As customers make a connection between a radical innovation and its past interactions with the firm and its products, reputation then helps customers perceive less risk associated with radical innovation (Dowling and Staelin 1994). Thus:

H5: The greater the reputational resources, the higher the likelihood that radical product innovation activity will promote the financial performance of the firm.

Relational resources will boost the ability of firms to benefit from radical innovation activity. The firm's social capital rests semi-permanently in its existing relationships and access to a web of customer and channel connections offer firms an opportunity to craft appropriate marketing and launch strategies. Strong relational resources enable the firm to better predict which radical innovations best fit its suppliers, customers, and clients. This increases the likelihood that a new product offering will hit a market window. For example, relational resources can help a firm to leverage its radical innovation in application domains relevant to its customers and relations with distribution channels can increase the adoption rate of a new product offering. Strategic allies can also act as intermediaries between the innovating firm and the marketplace when the firm's knowledge base is incompatible with the new market (O’Connor 1998). Stronger, closer, and longer-held relationships can then enable firms to better utilize and exploit their radical innovations in search of financial gains.

Relational resources can also enable a firm to access partners' assets to adapt rapidly to the market challenges posed by commercializing radical innovations (Ettlie and Pavlou 2006). Pooling complementary assets with channel partners can provide a more effective route to market, which 
helps firms reap the benefits of their innovation (Teece 1986; Tripsas 1997). For example, radical innovations in typesetting industry benefited from relational assets such as the sales and service network, innovators could deploy when commercializing their innovations to meet the needs of their B2B customers such as newspapers and commercial printers (Tripsas 1997). The firm’s stock of relational resources can also serve as bridges to new ties that may be required to successful launch and profit from a radical innovation (Hughes and Perrons 2011). Hence, relational resources should improve the ability of a firm to commercialize profitably by accessing partners' knowledge and assets to improve its product offering and routes to market (Rothaermel 2001). Thus:

H6: The greater the relational resources, the higher the likelihood that radical product innovation activity will promote the financial performance of the firm.

\section{Research Methods}

\section{Research Setting and Data Collection Procedures}

A sample of the largest (over 50 employees) 980 Dutch B2B business units from technologically intensive industries was drawn from the Dunn \& Bradstreet business directory. A business unit is a profit center with distinct products and markets and captures a standalone firm or one part of a larger corporate group. These technologically intensive industries consist of: fine chemicals (SICcode 28); industrial and commercial machinery and computer equipment (SIC-code 35); electronic and other electrical equipment and components, except computer equipment (SIC-code 36); transportation equipment (SIC-code 37); and measuring, analyzing and controlling instruments, and photographic, medical, and optical goods, watches, and clocks (SIC-code 38). These sectors are characterized by high R\&D spend, patents, and new product introductions.

Several criteria guided the choice of our research setting: (1) as the value of marketing is typically asserted in rather stable environments, the literature can benefit from exploring the value of marketing resources in turbulent environments (Aaker and Jacobson 2001; Sorescu et al. 2003) 
and (2) our reliance on B2B firms offers a more homogenous setting to examine our key constructs (e.g., reputation resides in corporate brand image rather than in individual brand equities, as is often the case in B2C firms).

Marketing managers, or general managers if marketing managers were not listed, were selected as key informant given their involvement with marketing resources and product innovation (Jaworski and Kohli 1993). First, respondents were mailed a packet with a cover letter explaining the purpose of the research and promising a benchmarking report, the survey, a small incentive, and a pre-paid envelope. Approximately four weeks after the first mailing, follow-up phone calls were conducted with those companies that had not yet returned the questionnaire. The phone calls were used to check whether the package was delivered to the right person and to crosscheck whether the business unit was appropriate for the research. Two hundred and seventy-nine firms returned the questionnaire noting they are not performing manufacturing activities (active in wholesaling or retailing or just headquarters) and they were eliminated resulting in a sample of 701 firms. Of the eligible sample 111 firms returned the questionnaire for a response rate of $15.8 \%$. ${ }^{\text {ii }}$ Fifty five respondents were marketing executives and 33 were general managers while 23 were managers or directors with no set title.

The informants showed high levels of experience with the firm and with the tasks of interest. ${ }^{\text {iii }}$ Differences between respondents and non-respondents are checked for and no response bias is found (firm size respondents $=240$ employees, firm size non- respondents $=265$ employees, $\mathrm{t}=.284$, $\mathrm{p}=.77$ ). Response bias is also examined for with respect to their experience, the importance of tasks, and their level of involvement with insignificant results once again. Finally, in an effort to contain demand bias and yes-saying, all constructs contain multiple items and the innovation construct contains both negatively and positively phrased items (Tellis et al. 2009).

\section{Measures}


Existing measure scales are relied on to tap radical innovation activity and marketing resources (Table 1). All constructs were measured at the business unit (firm) level. To ensure that respondents were able to discern radical innovations from other types of innovation, three steps are followed (Chandy and Tellis 1998). First, they were provided with a definition of radical innovation coupled with an example. Then respondents were asked to rate the radicality of three innovations on a 7-point scale (microwave over conventional ovens, word processors over conventional typewriters, and quartz over hand-wound clocks).

Second, respondents were asked to mention the most radical innovation in their industry introduced in the last three years. Third, they were asked to describe the most radical innovation their business unit had introduced in the last three years including the technology employed and its customer benefits. Adequate information was provided by the respondents to steps 2 and 3 to determine that respondents could identify and describe radical innovations. In relation to the first test, the mean score for this scale was $5.014(\mathrm{SD}=0.896)$. Seven respondents scored below 4.00 and were removed from the analysis. The final sample for data analysis totaled 104 firms.

Respondents were asked to rate the inclination of their business unit to develop and introduce radical product innovations over the last three years with three scales from Chandy and Tellis (1998): a 4-item 7-pt Likert scale, a numerical scale tapping the number of radical innovations and a 6-bracket ordinal scale tapping the percentage of sales accounted for by radical innovations (all measures were standardized prior to scale construction in confirmatory factor analysis). As defined, these measures capture radical product innovation activity. As a further check, respondents were asked to mention the percentage of sales accounted for by all new products introduced by their SBU the last 3 years. In all cases, the latter was much larger (median: $10-20 \%$ of sales) than the former (median: $1-5 \%$ of sales) which is in the range reported by prior work for high-tech industries (Sorescu et al. 2003). Finally, on average, firms introduced 1.4 radical innovations in the last 3 years prior to the survey. ${ }^{\text {iv }}$ 
Measures for marketing resources were sourced from Morgan et al. (2006). Items for market knowledge resources focus on knowledge or experience about customers, competitors, channels, and the industry overall. Items for relational resources capture the strength, quality, duration, closeness, and number of customer/channel relationships. Reputational resources items measure the awareness, strength, distinctiveness, reputation, and appeal of the corporate image. All resources are measured relative to major competitors to provide a clear and common basis for each respondent, and consistent with conceptual work that resources are only meaningful when assessed relative to competition (Morgan et al. 2009).

Although output measures of marketing resources exist (e.g., market share, Moorman and Slotegraaf 1999), they are more suitable to gauging the impact of an overall marketing capability than to examine the differentiated effects of various marketing resources. In support of a surveybased approach, Krasnikov and Jayachandran (2008) argued that marketing resources are deeply rooted such that subjective evaluations may better capture their nuances.

Financial performance of the business unit is measured with a 4-item scale on overall profit, sales margin, return on equity, and return on assets (Desphandé et al. 1993). Objective data about financial performance was also sought. Using the Dunn \& Bradstreet database, data was collected on return on assets and return on equity on the subsequent year following the 3-year period respondents used to assess their SBU's radical innovation. Despite the small number of data (38 firms), our perceptual and objective measures were significantly correlated $(.34, p<.06)$.

The study controls for the size of a SBU (the natural log of the number of employees) to rule out the possibility that large size explains the variance in the focal outcomes (Chandy and Tellis 2000). Following prior theory (Moorman and Slotegraaf 1999), the financial and technological resources of the firm are also accounted for. Financial resources are measured with scales from Morgan et al. (2006) and technological resources are measured using the scales of Slotegraaf, Vorhies, and Morgan (2004). Following prior studies on innovation such as Moorman and 
Slotegraaf (1999) and Morgan et al. (2006), technological resources are viewed as embodying patented, technical, and scientific knowledge. Competitive turbulence was controlled for to ensure that our results are not a function of the level of change in the firm's environment (Jaworski and Kohli 1993). The structure of the firm is also controlled for by measuring centralization using the scale of Matsuno et al. (2002). These scales are summarized in Table 1.

Measurement items were removed from the analysis if factor loadings were poor. The remaining items were entered into two confirmatory factor analyses (CFA) to assess measurement model fit. Two CFA models were specified so as not to exceed the parameter-to-observation ratio (5:1). Model 1 included all resource items and Model 2 contained all other items. The CFA model fit statistics reveal acceptable model fit. Model 1: $\chi^{2}$ (d.f.) $=233.96(160) ; p=.00 ; \chi^{2} /$ d.f. $=1.46$; RMSEA $=.07 ; \mathrm{CFI}=.97 ; \mathrm{NNFI}=.96 ; \mathrm{IFI}=.97$. Model $2: \chi^{2}$ (d.f.) $=99.85(68) ; p=.01 ; \chi^{2} /$ d.f. $=$ $1.47 ; \mathrm{RMSEA}=.07 ; \mathrm{CFI}=.93 ; \mathrm{NNFI}=.91 ; \mathrm{IFI}=.93$.

Table 1 contains the measurement properties for all items and Table 2 contains the descriptive statistics of the constructs. All CR values exceed accepted thresholds. Whilst AVE is lower than preferred in some cases they are not inconsistent with prior research and as the square root of all AVE values exceed the correlations it is shown that discriminant validity exists. To further confirm discriminant validity, the t-values of all items are significant at the $1 \%$ level, although for the control variable of 'competitive turbulence' the significance is at 5\%.

The external (face) validity of the radical innovation measure is checked by examining its correlations with other variables that are theoretically related to our radical innovation measure. Two single item scales (Gatignon et al. 2002) are utilized that tapped technology and market radicalness of innovations. These two dimensions also constitute radical innovation and hence are expected to correlate with radical innovation. Both these measures were positively correlated with radical innovation $(\mathrm{b}=.66, \mathrm{p}<.01$ and $\mathrm{b}=.45, \mathrm{p}<.01)$. Likewise innovativeness-defined as a 
firm culture valuing risk taking and creativity (Matsuno, Mentzer, and Özsomer 2002)—was positively correlated with radical innovation $(\mathrm{b}=.21, \mathrm{p}<.05)$.

\section{Common Method Variance Tests}

As the dependent and independent variables were obtained from a single key informant, common method bias is tested in four ways. First, following Lindell and Whitney (2001), a marker variable (radicality of quartz clocks over hand wound clocks) which is theoretically unrelated to our focal constructs is inspected. The correlations of this with the study variables were insignificant $(-.16<\mathrm{b}$ $<.15, p>$.13). Second, the Harman one-factor test was used (Podsakoff et al. 2003). The results of the principal components factor analysis revealed eight factors with eigenvalues greater than 1.0, and correspond to the eight constructs in our model. Further, there does not appear to be a CMV concern as results indicated there is no general factor in the unrotated factor structure.

Third, the second test is extended and a single CMV factor using CFA is specified (e.g., Malhotra Kim, and Patil 2006; Hughes, Hughes, and Morgan 2010). This model is worthy of rejection: $\chi^{2}$ (d.f.) $=1848.47(527) ; p=.00 ; \chi^{2} /$ d.f. $=3.51 ;$ RMSEA $=.16 ;$ CFI $=.70 ; \mathrm{NNFI}=.68$; IFI $=$.70. Fourth, following Malhotra et al. (2006) the marker variable technique is used to examine for CMV issues within both CFA Models 1 and 2. The same marker variable is used as previously. Given the use of maximum likelihood estimation using the covariance matrix in LISREL 8.8, a more robust examination of CMV should examine how covariance between variables is affected by the common method at hand. Average covariance was calculated (c.f. Malhotra et al. 2006) as: $\mathrm{r}_{\mathrm{m}}=$ -0.107 for CFA Model 1 and $r_{m}=-0.006$ for CFA Model 2. From this, CMV-adjusted covariances were calculated for CFA Models 1 and 2. The modified covariance matrix for each CFA Model was then used by re-specifying the original CFA Models.

The results show that with CMV-adjusted covariance, the changes in the CFA Models were non-significant and did not materially affect model fit. For CFA Model $1^{\mathrm{v}}$, adjusting to remove CMV resulted in a negligible change in model fit: $\Delta \chi^{2}=+8.83 ; \Delta \mathrm{df}=0 ; \Delta \mathrm{RMSEA}=0.01 ; \Delta \mathrm{CFI}$, 
NNFI, IFI $=.00$ ). For CFA Model $2^{\mathrm{vi}}$, adjusting to remove CMV resulted in a negligible change in model fit: $\left.\Delta \chi^{2}=-0.49 ; \Delta \mathrm{df}=0 ; \Delta \mathrm{RMSEA}=0.00 ; \Delta \mathrm{CFI}, \mathrm{IFI}=-.01 ; \Delta \mathrm{NNFI}=-.02\right)$. Once again, this change is not statistically significant. In examining the factor loadings of the items contained in the CMV-adjusted CFA Models, there were no significant changes in any factor loadings and a recalculation of all CR and AVE values showed no changes either. Though these tests do not rule out CMV completely, they do suggest that CMV is unlikely present in the dataset (Malhotra et al. 2006).

\section{Hypotheses Testing Approach}

Hypotheses were tested using the covariance matrix and maximum likelihood estimation in LISREL 8.80. Ping's (1995) protocol for estimating and evaluating structural equation models with moderator terms are followed. After obtaining estimates of the error variances and factor loadings for each moderator term through Ping's (1995) protocol, a restricted and an unrestricted structural model were specified. Both models include all constructs and controls; however, they differ in that the $\gamma$ parameters linking the moderator terms to performance were fixed at zero and the remaining $\gamma$ parameters were freely estimated in the restricted model, whilst all $\gamma$ parameters were freely estimated in the unrestricted model. All constructs were summated when used for structural equation modeling so as to reduce the burden on the data and not exceed the parameterto-observation ratio. The results of the unrestricted model were superior to the restricted one and are therefore used for hypothesis testing. The unrestricted model fit statistics were: $\chi^{2}$ (d.f.) $=6.49$ $(7) ; p=.48 ; \chi^{2} /$ d.f. $=.93 ;$ RMSEA = .00; CFI = .99; NNFI = .99; IFI = .99; GFI = .99.

\section{Results}

The first set of hypotheses relate to the direct effects of marketing resources on radical innovation. The square term of market knowledge is insignificant $(\gamma=-.14 ; p>.10)$, failing to support $\mathrm{H}_{1}$. 
However, a negative direct effect by market knowledge resources on radical innovation was found, instead $(\gamma=-.09 ; p \leq .05)$. Reputational resources negatively affect radical innovation $(\gamma=-.22 ; p \leq$ .10), supporting $\mathrm{H}_{2}$, whilst relational resources benefit radical innovation $(\gamma=.45 ; p \leq .01)$, supporting $\mathrm{H}_{3}$. Though not hypothesized, size (number of employees) boosts radical innovation activity.

The second set of hypotheses relating to the interaction effects of marketing resources on the relationship between radical innovation and financial performance are supported. Market knowledge resources decrease the effects of radical innovation on performance $(\gamma=-.63 ; p \leq .05)$ but reputational $(\gamma=.28 ; p \leq .05)$ and relational resources $(\gamma=.26 ; p \leq .05)$ have strong positive moderating effects and strengthen the relationship between radical innovation and financial performance. Therefore, $\mathrm{H}_{4}, \mathrm{H}_{5}$, and $\mathrm{H}_{6}$ are supported. Radical innovation had no direct relationship with performance $(\gamma=.06 ; n s)$.

To determine the additional variance explained by the interaction terms, comparisons between the squared multiple correlations for reduced form values for financial performance across the restricted and unrestricted SEM models (as discussed previously) are made. The restricted SEM model does not include the interaction effects on performance. In this model, the value is 0.23 . Thus $23 \%$ of variance in performance is explained. The unrestricted model includes the paths for the interaction effects and in this model the value rises to 0.39 . This is a $69 \%$ increase in the variance explained when the interaction terms are included in the model.

The robustness of our results is explored across an alternative model. The RBV literature stresses the complementary nature of resources (Moorman and Slotegraaf 1999; Song et al. 2005); as such, some resources work together to create innovation benefits. Such a model is tested for by including three two-way interactions among the marketing resources. Technological resources are also controlled for as an additional determinant of performance. The results show this model $\left(\chi^{2}\right.$ 
[d.f.] $=8.59$ [9]) is not superior to the current model as the difference in chi-square is nonsignificant $\left(\Delta \chi^{2}\right.$ [d.f.] = .60 [2]; $\left.p=74\right)$. The additional interactions resulted in low path estimates ( $\gamma$ ranging from -.12 to .03) bearing no significant effects on the model. Furthermore, technological resources $(\gamma=.02 ; n s)$ had no direct effect on financial performance.

[Insert Tables 12 , and 3 here]

\section{Discussion and Conclusions}

\section{Summary of our results and their implications}

Contemporary work on visioning new markets (Reid and de Brentani 2010, 2012) and the persistent failure of radical innovations to deliver value (Barczak et al. 2009) suggest that our cumulative understanding of radical innovation activity and of marketing resources therein is far too thin. Our research sought to unravel the ambivalent role of marketing in radical innovation, a vexing priority amidst the increasing importance of breakthrough innovation in long-term competitive advantage (e.g., Slater et al. 2014; Sorecsu and Spanjol 2008). Applying the attentionbased view of the firm to the market-based assets, our study is the first to examine the role of a comprehensive set of marketing resources in driving attention to and away from radical innovation activity and as moderators of its link to firm performance in B2B technology-based firms. Gleaning ideas from the attention-based view to understand how market-based assets affect radical innovation activity and its payoffs, it was theorized that the failure to understand the attentiondirecting nature of marketing knowledge, reputational, and relational resources explains the ambivalent role of marketing resources in radical product innovation activity.

As a summary of the findings, (a) market knowledge resources hurt both radical innovation activity and its financial rewards, (b) reputational resources come with a trade-off as they hurt the incidence of radical innovation but enhance its financial rewards, (c) firms with strong relational 
resources enjoy a higher propensity for and stronger financial rewards from radical innovation. We turn, first, to an elaboration of our findings and then we offer several contributions to theory, knowledge, and practice.

Beginning with market knowledge resources, our hypothesis of an inverted-U shaped relationship with radical innovation activity did not hold. An analysis of the direct effect alone however revealed that market knowledge resources hurt radical innovation activity. At the same time, its debilitating role in the payoffs of radical innovation is consistent with our hypothesis. One possible explanation for these harmful effects has to do with the nature of market knowledge as captured in this study. Our measure of market knowledge tends to reflect accumulated prior knowledge about current customer or markets rather than new ones. Echoing the 'tyrannical' view of prior knowledge in which managers repeat a similar set of activities (e.g., Autio et al. 2000; Chandy and Tellis 1998; Zhou et al. 2005), knowledge-rich firms stumble in their efforts to engage or benefit from their radical innovation activity. Their entrenched beliefs about current customers, competitors or channels avert managers’ attention to new opportunities.

These two findings are not to deny upfront the role of prior market knowledge which can fuel the assimilation and utilization of new knowledge crucial to the innovation process (Atuahene-Gima 2005; Prabhu et al. 2005; Slater and Narver 1999). Rather, our results suggest that researchers should be sensitive not only to the size but also the content of market knowledge resources (Kyriakopoulos and de Ruyter 2004) a firm has and how these direct the attention of managers to new lines of inquiry or away from new lines of inquiry. For example, communication firms with accumulated expertise in optical fibers had a greater propensity to respond to technical change (Kaplan 2008).

But even with these caveats, our results challenge the principal assumption in market orientation literature about the need to develop customer-oriented market knowledge resources (e.g., Atuahene-Gima 2005; Moorman and Miner 1997) and its prominent role in best practices in 
leading NPD firms, which include a focus on providing adequate resources to support the market research function and generating detailed market knowledge on customers and competitors therein (Kahn et al. (2012). In our research, market knowledge resources emerge as potent but problematic attention-guiding devices. While market knowledge resources inform managers’ decisions and market vision about radical product definition (Berchicci and Tucci 2010; Reid and de Brentani 2010, 2012), firms may fail in developing the sort of market visions conducive to radical innovation because they are grounded in the past experiences of the firm in its markets. Attention is then diverted towards incremental innovation activity—a problem acknowledged by radical innovation scholars (Garcia 2005; Reid and de Brentani 2010).

Turning to reputational resources, their negative effect on radical innovation activity and positive effect in benefiting from it implies a paradox when a firm invests in its corporate image. Support is found for concerns that reputation can inhibit the willingness to go beyond existing products (Chandy and Tellis 2000), but results also reaffirm a second strand of theory that asserts reputational assets can increase the payoffs from radical innovation activity (Brown and Dacin 1997). This paradox can be deciphered when combining a resource-based and an attention-based view to study the effects of this resource. Reputable firms have higher risk from abandoning proven products and reputable market positions, reducing the motivation of managers to pursue breakthrough innovations.

But once radical innovations are developed and managerial attention shifts to commercialization, the ability of reputational resources to direct the attention of customers can aid value appropriation from radical innovation activity. Reputation and corporate image evoke established expectations about quality from past corporate brand associations, reducing customers' uncertainty around new products. This research therefore contributes new knowledge by revealing that this paradox can be deciphered when an attention-based lens is implied to study the properties of the resource. 
Finally, relational resources appear to be critical in fostering and benefiting from radical innovation. Interfirm research in product innovation has established the importance of close ties with customers and channel partners in innovative activities at both at dyadic and network levels (Cui and O’Connor 2012; Emden et al. 2006; Noordhoff et al. 2011) on the premise that social capital eases the transfer of tacit and proprietary knowledge (e.g., Nahapiet and Ghoshal 1998; Rindfleisch and Moorman 2001). While our results resonate with this view, they also demonstrate that relational resources foster an overlooked, yet important class of innovation outcomes — radical innovation.

\section{Contributions to Product Innovation and Marketing Research}

Researchers have repeatedly called for more research on the role of marketing in radical innovation (e.g., Atuahene-Gima et al. 2005; Tellis et al. 2009; Zhou et al. 2005). A key advantage of our approach is that it offers a more holistic and comprehensive framework on the role of marketing resources in radical innovation than previous work, which oscillates between a narrow focus on certain marketing activities (advertising by Sorescu et al. 2003; Sorescu and Spanjol 2008) or an aggregate marketing capability (e.g., market share by Moorman and Slotegraaf 1999). Consistent with recent work (e.g., Baker and Sinkula 2005; Morgan et al. 2009), our subjective measures also offer a more direct assessment of marketing resources instead of aggregate proxies - though not problem-free as is discussed later. Finally, the reliance on a broader sample of high-tech B2B industries extend prior work focusing on single industries.

Our use of the attention-based view extends NPD research that recognizes the role of managerial attention in radical innovation in passing. O’Connor and Rice (2013, p.2) specify that, "Large established firms typically focus on enhancing their ability to manage their core businesses, with an emphasis on cost reduction, quality improvements, and incremental innovation in existing products and processes.” This suggests that managers’ attention is already primed against radical innovation activity. Relatedly, Debruyne et al.’s (2010) ‘liability-of-wealth’ hypothesis suggests 
that large resource stocks further divert managers' attention by coloring their view of their real ability to innovate and respond to the radical innovation activity of others.

While both these studies speculate about the problem of attention, this research shows how marketing resources channel manager attention and demonstrate how this can explain the incidence of radical innovation activity. The findings add theoretical and empirical richness to explain the phenomena reported by O’Connor and Rice (2013) and Debruyne et al. (2010). It is also shown how marketing resources redirect managers' attention when engaging with the problem of benefiting from the firm's radical innovation activity. The conclusion is made that 'liability of wealth' is not the problem, but liabilities caused by how stocks of marketing resources orient managers' attention and decision-making. A resource-based view alone fails to appreciate how resources guide managers' attention to and from activities that these resources are themselves then allocated to. This research therefore offers a new contribution integrating an attention-based view into analyses of market-based assets and radical innovation activity.

Finally, contribution is made to the theoretical development of the attention-based view by answering some of its unanswered questions. Though, it recognizes the attention-shaping properties of firm resources, Ocasio’s (1997) seminal work did not integrate a resource-based perspective, leaving open the question of what resources selectively focus managers' attention, why, and the business implications therein. Prior work has revealed some connections between the structure of firm attention, resources, and innovation, for example, the attention focus of senior leaders affects communication firms’ response to the optical-fiber revolution (Kaplan 2008) and the organizational adaptation in GE (Joseph and Ocasio 2012). These studies are extended as the focus on radical innovation activity offers a prime context in which to study the effects of managerial attention being channeled in unforeseen ways. Our effort should be seen as an initial stride into the attention-guiding properties of resource stocks, largely overlooked in the RBV. With this caveat in mind, our contribution lies in showing that marketing resources offer a mixed 
portrait of channeling attention towards and away radical innovation as a function of the type of resources and their effects in the occurrence vs. the payoffs of radical innovation activity. Implications for Practice

Leading NPD firms do generate detailed market knowledge on customers and competitors (Kahn et al. 2012). While its value is not denied here, the results caution that in excess such resources bind the firm to its present markets. By focusing managers' attention in this way, it reduces radical innovation activity. Extensive current market knowledge comforts managers to remain with existing products and customers at the expense of radical innovation activity. Thus, while knowledge is a valuable, rare, and difficult-to-imitate resource built over time, its intrinsic value is too often tied in the firm's current activities and served markets. The diminishing returns from this resource suggests that managers should be conscious of its attention-guiding properties over its resource-based properties, and consider what exploratory activities are needed to ensure a wider spectrum of knowledge enters the firm and is acted on.

Managers must be acutely aware of how marketing resources direct attention to or from radical innovation activity, and influence the accrual of financial reward from it. The positive effects of relational resources in both of these respects suggests that firms should avoid selfreliance and instead develop an outward focus to build relational resources with customers, suppliers, and distribution channels. Managers will need to invest time to build the requisite social capital so that this resource becomes valuable and rare and capable of exposing the firm to new knowledge and resources of value to radical innovation activity.

Managers must balance the need to cultivate corporate image against its potential to subvert radical innovation activity. Strong reputation resources exhibit inertial properties but because of the investment and marketing messages tied in them, they are particularly beneficial in generating financial rewards from radical innovation activity. Thus, while reducing the amount of 
radical innovation activity taking place, they do enable firms to gain more from it as these resources can leverage the attention and goodwill of customers.

\section{Study Limitations and Future Research}

The study contains some limitations. First, a single informant approach is used but with actions taken to ensure robust data collection. Securing sufficient support for a survey is regularly underestimated. Most of our theoretical constructs rely on internal informants if it is to be possible to gauge them with high fidelity. Nevertheless, this reliance on primary data leaves room for future research to use secondary data to measure our theoretical constructs where possible. Secondary data on resources are not problem-free as they fail to provide face valid measures and the proxy measures that are often used in objective data collection cannot get at the heart of measuring resources (Krasnikov and Jayachandran 2008). It was not possible to access objective data but future studies may look to merge subjective measures with objective ones where possible. Second, investigating our theory longitudinally will expand its implied causal chain.

To further understand why specific resources might antagonize radical innovation activity, future research should examine whether firms fully deploy their resources to fuel or benefit from radical innovation activity; how firms allocate resources that may further divert attention from radical innovation activity; and why resources might not be mobilized sufficiently. Such a research agenda will help us address a shortcoming in our measures that capture the levels of specific firm resources and not their actual use in the radical innovation activity.

Our results offer important avenues for future research. First, the harmful effects of knowledge resources call for further research in the type of market knowledge resources (the extent they reflect experience with current markets vs. new markets to the firm) and their effects in the development and commercialization of radical innovations. Given prior research establishing the poisonous role of knowledge about current customers in disruptive innovations (Christensen and Bower 1996) and the debate on the role of reactive vs. proactive market orientation (Tellis et 
al. 2009; Slater and Narver 1999), this distinction is likely crucial to generating a finer understanding of the role of market knowledge resources in radical innovation.

While the effects of stocks of specific market resources on radical innovation activity are examined here, a related question is whether configurations of resources affect radical innovation activity in novel or unexpected ways. Reid and de Brentani’s (2012) work on market visioning prioritizes the role of market knowledge in how visions of future markets form. However, available resources can affect what market visions form as implied in our work through the lens of the attention-based view. Both perspectives imply that the configuration of marketing resources might have further effects on radical innovation activity within firms.

An alternative lens for examining the negative impact of reputational resources relates to the observation that many technology-driven firms with strong corporate brand and reputation resources do innovate considerably, such as Samsung, or Intel. The reputation of the firms is built around their entrepreneurial heritage that orients managerial attention to radical innovation (Dutta et al. 1999). While our view of reputation stresses the strength of the corporate image consistent with Weiss et al.'s (1999, p. 75) definition of reputation as “the extent to which an organization is held in high esteem or regard”, it is important to explore alternative definitions of reputation resources, for example, reputation as a proxy of product innovation or toughness (see Roberts and Dowling 2002).

Finally, aligned and unaligned radical innovation activity is not differentiated between in this study. This is potentially important because radical innovations, while representing new and different propositions to a market, can still be aligned to the past or current projects of a firm or be entirely unaligned. The resource implications might then be quite different as well as how such resources might direct the attention of managers. Expanding on these dimensions can yield further insights into how attention is directed to and away from radical innovation activity. 


\section{Conclusion}

The primary contribution of this study is the framing and testing of a unified model of the role marketing resources play in radical innovation activity. By attaching an attention-based view of the firm to a market-based assets view, this research empirically demonstrates the links between market knowledge, reputational, and relational resources and radical innovation, as its antecedents and as moderators of its links with firm financial performance in B2B high-tech industries. The research and findings underscores the differentiated value of marketing in radical innovation activity contrary to the entrenched idea of a limited or even stifling role of marketing in this context. 


\section{Acknowledgements}

We are grateful to Rajesh Chandy, Robert Morgan, Luigi de Luca and Doug Vorhies for their constructive comments on earlier versions of this article. 


\section{References}

Aaker, D. A. 2004. Leveraging the corporate brand. California Management Review 46(3): 6-18.

Aaker, D. A., and R. Jacobson. 2001. The value relevance of brand attitude in high-technology markets. Journal of Marketing Research 38(4): 485-493.

Atuahene-Gima, K. (2005). Resolving the capability-rigidity paradox in new product innovation. Journal of Marketing 69(4): 61-83.

Autio, E., H. J. Sapienza, and J. G. Almeida. 2000. Effects of age at entry, knowledge intensity, and imitability on international growth. Academy of Management Journal 43: 909-924.

Baker, W. E., and J. M. Sinkula. 2005. Market orientation and the new product paradox. Journal of Product Innovation Management 22(6): 483-502.

Barczak, G., A. Griffin, and K. B. Kahn. 2009. Perspective: Trends and Drivers of Success in NPD Practices: results of the 2003 PDMA Best Practices Study. Journal of Product Innovation Management 26(1), 3-23.

Barney, J. B. 1991. Firm resources and sustained competitive advantage. Journal of Management 17(1): 99-120.

Berchicci, L., and C. L. Tucci. 2010. There is more to market learning than gathering good information: The role of shared team values in radical product definition. Journal of Product Innovation 27(7): 972-990.

Bower, J. L., and C. M. Christensen. 1995. Disruptive technologies: Catching the wave. Harvard Business Review 73(1): 43-53.

Brown, T. J., and P. A. Dacin. 1997. The company and the product: Corporate associations and consumer product responses. Journal of Marketing 61(1): 68-84.

Capron, L., and J. Hulland. 1999. Redeployment of brands, sales forces, and general marketing management expertise following horizontal acquisitions: A resource-based view. Journal of Marketing 63(2): 41-54.

Chandy, R. K., and G. J. Tellis. 1998. Organizing for radical product innovation: The overlooked role of willingness to cannibalize. Journal of Marketing Research 35(4): 474-487.

Chandy, R. K., and G. J. Tellis 2000. The incumbent's curse? Incumbency, size, and radical product innovation. Journal of Marketing 64(3): 1-17.

Christensen, C. M., and J. L. Bower 1996. Customer power, strategic investment, and the failure of leading firms. Strategic Management Journal 17(3): 197-218.

Cohen, M. W., and D. A. Levinthal. 1990. Absorptive capacity: A new perspective on learning and innovation. Administrative Science Quarterly 35(1): 128-152.

Cooper, A., and C. Smith. 1992. How established firms respond to threatening technologies. Academy of Management Executive 6(2): 55-70.

Cui, A. S., and G. O’Connor. 2012. Alliance portfolio resource diversity and firm innovation. Journal of Marketing 76(4): 24-43.

Danneels, E. 2004. Disruptive technology reconsidered: A critique and research agenda. Journal of Product Innovation Management 21(4): 246-258.

D’Aveni, R. A. 1995. Coping with hypercompetition: Utilizing the new 7S's framework. Academy of Management Executive 9(3): 45-60.

Day, G. S. 1994. The capabilities of market-driven organizations. Journal of Marketing 58(4): 37-52. 
Debruyne, M., R. T. Frambach, and R. Moenaert. 2010. Using the weapons you have: The role of resources and competitor orientation as enablers and inhibitors of competitive reaction to new products. Journal of Product Innovation Management 27(2): 161-178.

Deshpandé, R., J. U. Farley, and F. E. Webster Jr. 1993. Corporate culture, customer orientation, and innovativeness in Japanese firms: a quadrad analysis. The Journal of Marketing 57(1):2337.

Dowling, G. R., and R. Staelin. 1994. A model of perceived risk and intended risk-handling activity. Journal of Consumer Research 21(1): 119-134.

Dutta, S., O. Narasimhan, and S. Rajiv. 1999. Success in high-technology markets: is marketing capability critical? Marketing Science 18(4): 547-568.

Dutton, J. E., and S. J. Ashford 1993. Selling issues to top management. Academy of Management Review 18(3): 397-428.

Emden, Z., R. J. Calantone, and C. Droge. 2006. Collaborating for new product development: Selecting the partner with maximum potential to create value. Journal of Product Innovation Management 23(4): 330-341.

Ericksen, M., J. Jullens, and G. Kataria. 2009. The new B2B marketing imperative: Developing fundamental capabilities to capture market share. Chicago, IL: Booz and Company.

Ettlie, J. E., and P. A. Pavlou 2006. Technology-based new product development partnerships. Decision Sciences 37(2): 117-147.

Ettlie, J. E., W. P. Bridges, and R. D. O’Keefe. 1984. Organization strategy and structural differences for radical versus incremental innovation. Management Science 30(6): 682-695

Evanschitzky, H., M. Eisend, R. J. Calantone, and Y. Jiang. 2012. Success Factors of Product Innovation: An Updated Meta-Analysis. Journal of Product Innovation Management 29(S1): 21-37.

Garcia, R. 2005. Uses of agent-based modeling in innovation/new product development research. Journal of Product Innovation Management 22(5): 380-398.

Gatignon, H., M. L. Tushman, W. Smith, and P. Anderson. 2002. A structural approach to assessing innovation: Construct development of innovation locus, type, and characteristics. Management Science 48(9): 1103-1122.

Govindarajan, V., P. K. Kopalle, and E. Danneels. 2011. The effects of mainstream and emerging customer orientations on radical and disruptive innovations. Journal of Product Innovation Management 28(S1): 121-132.

Grant, R. M., and Baden-Fuller, C. 2004. A knowledge accessing theory of strategic alliances. Journal of Management Studies 41(1): 61-84.

Griffin, A., B. W. Josephson, G. Lilien, F. Wiersema, B. Bayus, R. Chandy, E. Dahan, S. Gaskin, A. Kohli, C. Miller, R. Oliva, and J. Spanjol. 2013. Marketing's roles in innovation in business-to-business firms: Status, issues, and research agenda. Marketing Letters 24(4): 323337.

Hamel, G., and C. K. Prahalad. 1994. Competing for the future. Boston, MA: Harvard Business School Press.

Heide, J. B., K. H. Wathne, and A. I. Rokkan 2007. Interfirm monitoring, social contracts, and relationship outcomes. Journal of Marketing Research 44(3): 425-433.

Henard, D. H., and D. M. Szymanski. 2001. Why some new products are more successful than others. Journal of Marketing Research 38(3): 362-375. 
Henderson, R., and I. Cockburn. 1994. Measuring competence? Exploring firm effects in pharmaceutical research. Strategic Management Journal 15(Winter Special Issue): 63-84.

Hughes, M., and R. Perrons. 2011. Shaping and re-shaping social capital in buyer-supplier relationships. Journal of Business Research 64(2): 164-171.

Hughes, P., M. Hughes, and R. E. Morgan. 2010. Why do product-market strategies fail? A sociostructural examination under conditions of adherence. Group \& Organization Management 35(5): 606-635.

Jansen, J.J.P., F.A.J. Van Den Bosch, and H.W. Volberda. 2006. Exploratory innovation, exploitative innovation, and performance: Effects of organizational antecedents and environmental moderators. Management Science 52: 1661-1674.

Jaworski, B. J., and A. K. Kohli. 1993. Market orientation: Antecedents and consequences. Journal of Marketing 57(3): 53-70.

Joseph, J., and W. Ocasio. 2012. Architecture, attention, and adaptation in the multibusiness firm: General Electric from 1951 to 2001. Strategic Management Journal 33(6): 633-660.

Kahn, K. B., G. Barczak, J. Nicolas, A. Ledwith, and H. Perks. 2012. An examination of new product development best practice. Journal of Product Innovation Management 29(2): 180 192.Kaplan S. 2008. Cognition, capabilities and incentives: assessing firm response to the fiber-optic revolution. Academy of Management Journal 51(4): 672 - 695.

Kaplan S. 2008. Cognition, capabilities and incentives: assessing firm response to the fiber-optic revolution. Academy of Management Journal 51(4): 672 - 695.

Krasnikov, A., and S. Jayachandran. 2008. The relative impact of marketing, research and development, and operations capabilities on firm performance. Journal of Marketing 72(4): 111.

Kerin, R. B., M. G. Harvey, and J. T. Rothe. 1978. Cannibalism and new product development. Business Horizons 21(5): 25-32.

Kyriakopoulos, K., and K. de Ruyter. 2004). Knowledge stocks and information flows in new product development. Journal of Management Studies 41(8): 1469-1498.

Leonard-Barton, D. 1992. Core capabilities and core rigidities: A paradox in managing new product development. Strategic Management Journal 13(Summer Special Issue): 111-125.

Levinthal, D. A., and J. Myatt. 1994. Co-evolution of capabilities and industry: The evolution of mutual fund processing. Strategic Management Journal 15(Winter Special Issue): 45-62.

Lindell, M. K., and D. J. Whitney 2001. Accounting for common method variance in crosssectional designs. Journal of Applied Psychology 86(1): 114-121.

Lindgren, L. M., and G. O’Connor. 2011. The Role of Future-Market Focus in the Early Stages of NPD across Varying Levels of Innovativeness. Journal of Product Innovation Management 28(5): 787-800.

Lynn, G. S., J. G. Morone, and A. S. Paulson. 1996.: Marketing and Discontinuous Innovation: The Probe and Learn Process. California Management Review 38(3): 8-16.

Malhotra, N. K., S. S. Kim, and A. Patil. 2006. Common method variance in IS research: A comparison of alternative approaches and a reanalysis of past research. Management Science 52: 1865-1883.

March, J.G. 1991. Exploration and exploitation in organizational learning. Organization Science 2(1): 71-87.

Matsuno, K., J. T. Mentzer, and A. Özsomer. 2002. The effects of entrepreneurial proclivity and market orientation on business performance. Journal of Marketing 66(3): 18-32. 
McDermott, C. M., and G. C. O’Connor. 2002. Managing radical innovation: An overview of emergent strategy issues. Journal of Product Innovation Management 19(6): 424-438

Moorman, C., and A. Miner. 1997. The impact of organizational memory on new product performance and creativity. Journal of Marketing Research 34(1): 91-106.

Moorman, C., and R. J. Slotegraaf. 1999. The contingency value of complementary capabilities in product development. Journal of Marketing Research 36(2): 239-257.

Morgan, N. A. 2012. Marketing and business performance. Journal of the Academy of Marketing Science 40(1): 102-119.

Morgan, N. A., D. W. Vorhies, and B. B. Schlegelmilch. 2006. Resource-performance relationships in industrial export ventures: The role of resource inimitability and substitutability. Industrial Marketing Management 35(5): 621-633.

Morgan, N. A., R. J. Slotegraaf, and D. W. Vorhies. 2009. Linking marketing capabilities with profit growth. International Journal of Research in Marketing 26(4): 284-293.

Noordhoff, C., K. Kyriakopoulos, C. Moorman, P. Pauwels, and B. G. C. Dellaert. 2011. The bright side and dark side of embedded ties in business-to-business innovation. Journal of Marketing 75(5): 34-52.

O’Connor, G. C. 1998. Market learning and radical innovation: A cross case comparison of eight radical innovation projects. Journal of Product Innovation Management 15(2): 151-166.

O’Connor, G. C., and M. P. Rice. 2013. A Comprehensive Model of Uncertainty Associated with Radical Innovation. Journal of Product Innovation Management 30(S1): 2-18.

O’Connor, G. C., and R. Veryzer. 2001. The nature of market visioning for technology-based radical innovation. Journal of Product Innovation Management 18(4):231-246.

Ocasio, W. 1997. Towards an attention-based view of the firm. Strategic Management Journal 18(S1): 187-206.

Ping, Jr., R. A. 1995. A parsimonious estimation technique for interaction and quadratic latent variables. Journal of Marketing Research 32(3): 336-347.

Pleatsikas, C., and D. Teece. 2001. The analysis of market definition and market power in the context of rapid innovation. International Journal of Industrial Organization 19(5): 665-693.

Podsakoff, P. M., S. B. MacKenzie, J-Y. Lee, and N. P. Podsakoff. 2003. Common method biases in behavioral research: A critical review of the literature and recommended remedies. Journal of Applied Psychology 88(5): 879-923.

Powell, W. W. 1998. Learning from collaboration: Knowledge and networks in the biotechnology and pharmaceutical industries. California Management Review 40(3): 228-240.

Prabhu, J. C., R. K. Chandy, and M. E. Ellis. 2005. The impact of acquisitions on innovation: Poison pill, placebo, or tonic? Journal of Marketing 69(1): 114-130.

Prahalad, C. K. and G. Hamel. 1990. The core competence of the corporation. Harvard Business Review 68(3): 79-91.

Reid, S. E. and U. de Brentani. 2010. Market vision and market visioning competence: Impact on early performance for radically new, high-tech products. Journal of Product Innovation Management 27(4): 50-518.

Reid, S. E. and U. de Brentani. 2012. Market vision and the front end of NPD for radical innovation: The impact of moderating effects. Journal of Product Innovation Management 29(S1): 124-139.

Roberts, P. W., and G. R. Dowling. 2002. Corporate reputation and sustained superior financial performance. Strategic Management Journal 23(12): 1077-1093. 
Rothaermel, F. T. 2001. Incumbent's advantage through exploiting complementary assets via interfirm cooperation. Strategic Management Journal 22(6-7): 687-699.

Rubera, G., and A. H. Kirca. 2012. Firm innovativeness and its performance outcomes: A metaanalytic review and theoretical integration. Journal of Marketing 76(2): 130-147.

Slater, S. F., and J. C. Narver. 1999. Market-oriented is more than being customer-led. Strategic Management Journal 20(12): 1165-1168.

Slater, S. F., J. J. Mohr, and S. Sengupta. 2014. Radical product innovation capability: Literature review, synthesis, and illustrative research propositions. Journal of Product Innovation Management 31(3): 552-566.

Slotegraaf, R. J., D. W. Vorhies, and N. A. Morgan. 2004. Marketing resources, effort and capability as drivers of financial performance. Working Paper, Indiana University, Kelley School of Business.

Song, M.X. and M.M. Montoya-Weiss. 1998. Critical development activities for really new versus incremental products. Journal of Product Innovation Management 15(2):124-135.

Song, M., C. Droge, S. Hanvanich, and R. J. Calantone. 2005. Marketing and technology resource complementarity: An analysis of their interaction effect in two environmental contexts. Strategic Management Journal 26(3): 259-276.

Sood, A., and G. Tellis. 2009. Do innovations really pay off? Total stock market returns to innovation. Marketing Science 28(3): 442-456.

Sorescu, A., R. K. Chandy, and J. C. Prabhu. 2003. Sources and financial consequences of radical innovation: insights from pharmaceuticals. Journal of Marketing 67(4): 82-102.

Sorescu, A. B., and J. Spanjol. 2008. Innovation's effect on firm value and risk: Insights from consumer packaged goods. Journal of Marketing, 72(2): 114-132.

Srivastava, R. K., L. Fahey, and H. K. Christensen. 2001. The resource-based view and marketing: The role of market-based assets in gaining competitive advantage. Journal of Management 27: 777-802.

Srivastava, R., T. Shervani, and L. Fahey. 1998. Market-based assets and shareholder value: A framework for analysis. Journal of Marketing 62(1): 2-18.

Stahl, F., M. Heitmann, D. R. Lehmann, and S. A. Neslin. 2012. The impact of brand equity on customer acquisition, retention, and profit margin. Journal of Marketing 76(4): 44-63.

Teece, D. J. 1986. Profiting from technological innovation. Research Policy 15(6): 285-305.

Tellis, G. J., J. C. Prabhu, and R. K. Chandy. 2009. Radical innovation across nations: The preeminence of corporate culture. Journal of Marketing 73(1): 3-23.

Tripsas, M. 1997. Unraveling the process of creative destruction: Complementary assets and incumbent survival in the typesetter industry. Strategic Management Journal 18(Summer Special Issue): 119-142.

Tripsas, M., and G. Gavetti. 2000. Capabilities, cognition, and inertia: Evidence from digital imaging. Strategic Management Journal 21(11): 1147-1161.

Utterback, J. M. 1994. Mastering the dynamics of innovation. Boston, MA: Harvard Business School Press.

van Heerde, H. J., C. F. Mela, and P. Manchanda. 2004. The dynamic effect of innovation on market structure. Journal of Marketing Research 41(2): 166-183.

Weiss, A. M., E. Anderson, and D. J. MacInnis. 1999. Reputation management as a motivation for sales structure decisions. Journal of Marketing 63(4): 74-89. 
Workman, J. P., Jr. 1993. Marketing's limited role in new product development in one computer systems firm. Journal of Marketing Research 30: 405-421.

Zhou, K. Z., C. K. Yim, and D. K. Tse. 2005. The effects of strategic orientations on technology and market-based breakthrough innovations. Journal of Marketing 69(2): 42-60. 
Table 1. Measurement Item Properties

\begin{tabular}{|c|c|c|c|c|}
\hline Construct & Measurement Item & $\begin{array}{l}\text { Standardized } \\
\text { Factor Loading }\end{array}$ & $\begin{array}{l}\text { Standard } \\
\text { Error }\end{array}$ & $t$-value \\
\hline \multirow{5}{*}{$\begin{array}{l}\text { Market } \\
\text { Knowledge } \\
\text { Resources }^{\mathrm{a}}\end{array}$} & Knowledge of competitors in this market. & .56 & .69 & 5.84 \\
\hline & Experience in doing business in this market. & .68 & .54 & 7.39 \\
\hline & Information and intelligence about the marketplace. & .85 & .28 & 10.11 \\
\hline & Knowledge of customers in this market. & .78 & .39 & 8.93 \\
\hline & Knowledge of the channel in this market. & .60 & .64 & 6.31 \\
\hline \multirow{4}{*}{$\begin{array}{l}\text { Reputational } \\
\text { Resources }^{\mathrm{a}}\end{array}$} & Awareness of our corporate name. & .78 & .40 & 9.35 \\
\hline & Strength of our corporate image. & .99 & .01 & 13.94 \\
\hline & Distinctiveness of our corporate image. & .84 & .29 & 10.49 \\
\hline & Reputation of our corporation. & .74 & .45 & 8.78 \\
\hline \multirow{4}{*}{$\begin{array}{l}\text { Relational } \\
\text { Resources }^{\mathrm{a}}\end{array}$} & Strength of existing customer/channel relationships. & .76 & .43 & 8.73 \\
\hline & Quality of customer/channel relationships. & .91 & .17 & 11.46 \\
\hline & Duration of relationships with current customers/channel. & .68 & .53 & 7.60 \\
\hline & Closeness of existing customer / channel relationships. & .82 & .34 & 9.68 \\
\hline \multirow{3}{*}{$\begin{array}{l}\text { Financial } \\
\text { Resources }^{\mathrm{a}}\end{array}$} & Level of financial resources available. & .92 & .15 & 11.98 \\
\hline & Access to financial capital. & .92 & .15 & 11.95 \\
\hline & Size of financial resources devoted to this business. & .80 & .36 & 9.68 \\
\hline \multirow[t]{5}{*}{$\begin{array}{l}\text { Technological } \\
\text { Resources }^{\mathrm{a}}\end{array}$} & $\begin{array}{l}\text { Technical and scientific knowledge and information relevant to } \\
\text { the industry. }\end{array}$ & .94 & .59 & 7.19 \\
\hline & Patented knowledge relevant to the industry. & .71 & .49 & 8.23 \\
\hline & New technical and scientific discoveries relevant to the & & & \\
\hline & industry. & .96 & .07 & 13.12 \\
\hline & Relevant discoveries by our technical and scientific personnel. & .95 & .09 & 12.87 \\
\hline \multirow[t]{4}{*}{ Centralization $^{\mathbf{b}}$} & $\begin{array}{l}\text { A person who wants to make his own decision would be } \\
\text { quickly discouraged here. }\end{array}$ & .75 & .44 & 8.31 \\
\hline & Even small matters have to be referred to someone higher up & & & \\
\hline & for a final answer. & .90 & .19 & 10.55 \\
\hline & I have to ask my boss before I do almost anything. & .78 & .39 & 8.82 \\
\hline \multirow{2}{*}{$\begin{array}{l}\text { Competitive } \\
\text { Turbulence }\end{array}$} & Competition in our industry is cutthroat. & .92 & .15 & 2.34 \\
\hline & There are many "promotion wars" in our industry. & .50 & .75 & 2.18 \\
\hline \multirow[t]{5}{*}{$\begin{array}{l}\text { Radical } \\
\text { Innovation }\end{array}$} & $\begin{array}{l}\text { This SBU lags behind in introducing radical product } \\
\text { innovations }{ }^{\mathrm{r}} \text {. }\end{array}$ & .67 & .55 & 6.45 \\
\hline & $\begin{array}{l}\text { This SBU has difficulty in developing radical product } \\
\text { innovations }{ }^{\mathrm{b}} \text {. }\end{array}$ & .93 & .13 & 8.60 \\
\hline & Please indicate the number of radical product innovations & & & \\
\hline & introduced by your SBU in the last three years ${ }^{c}$. & .37 & .86 & 3.61 \\
\hline & $\begin{array}{l}\% \text { of total sales from radical product innovations introduced in } \\
\text { the last three years }{ }^{\mathrm{d}} \text {. }\end{array}$ & .43 & .82 & 4.14 \\
\hline Size & Natural logarithm of number of employees & .82 & .32 & 9.76 \\
\hline \multirow{4}{*}{$\begin{array}{l}\text { Financial } \\
\text { Performance }^{e}\end{array}$} & Overall profit & .95 & .09 & 12.29 \\
\hline & Profit margin & .79 & .38 & 9.29 \\
\hline & Return on investments (ROI) & .71 & .49 & 8.10 \\
\hline & Return on assets (ROA) & .71 & .50 & 8.01 \\
\hline
\end{tabular}




\begin{tabular}{llc}
\hline Construct & Measurement Item & Standardized Standard $t$-value \\
Factor Loading Error
\end{tabular}

${ }^{\mathrm{a}}$ 7-point scale: ranging from much lower (1) to much higher (7) relative to main competitors.

b 7-point Likert scale.

${ }^{\mathrm{c}}$ Numeric scale.

d Ordinal scale: Less than 1\%; 1-5\%; 5-10\%; 10-20\%; 20-30\%; More than 30\%.

e 7 -pt scale: ranging from much worse (1) to much better (7) relative to main competitors.

r Reverse-coded item.

Table 2. Composite Reliabilities, Average Variance Extracted, Correlation Matrix, and Descriptive Statistics of Measures
1.
2.
3.
4.
5.
6.
7.
8.
9.
10.

\begin{tabular}{|c|c|c|c|c|c|c|c|c|c|c|}
\hline $\begin{array}{l}\text { 1. Market } \\
\text { knowledge } \\
\text { resources }\end{array}$ & $.70^{\mathrm{a}}$ & & & & & & & & & \\
\hline $\begin{array}{l}\text { 2. Reputational } \\
\text { resources }\end{array}$ & $.55^{* *}$ & .85 & & & & & & & & \\
\hline $\begin{array}{l}\text { 3. Relational } \\
\text { resources }\end{array}$ & $.52 * *$ & $.34^{* *}$ & .80 & & & & & & & \\
\hline $\begin{array}{l}\text { 4. Financial } \\
\text { resources } \\
\text { 5. Technological }\end{array}$ & $.50 * *$ & $.50^{* *}$ & $.32 * *$ & .88 & & & & & & \\
\hline resources & $.36 * *$ & $.49 * *$ & .18 & $.47^{* *}$ & .83 & & & & & \\
\hline 6. Centralization & -.10 & -.15 & -.17 & -.07 & -.10 & .81 & & & & \\
\hline $\begin{array}{l}\text { turbulence } \\
\text { 8. Radical }\end{array}$ & .01 & .03 & -.01 & .07 & .01 & .05 & .74 & & & \\
\hline innovation & .15 & $.22 *$ & $.25 * *$ & $.21^{*}$ & $.50 * *$ & -.06 & .01 & .64 & & \\
\hline $\begin{array}{l}\text { 9. Size } \\
\text { 10 Financial }\end{array}$ & -.03 & .10 & -.17 & .05 & -.04 & .19 & .17 & .06 & $n / a$ & \\
\hline - performance & $.38 * *$ & $.40 * *$ & $.21 *$ & $.48^{* *}$ & $.38 * *$ & -.03 & .01 & $.23 *$ & -.03 & .80 \\
\hline CR & .83 & .91 & .87 & .91 & .90 & .85 & .69 & .71 & $\mathrm{n} / \mathrm{a}$ & .87 \\
\hline AVE & .49 & .71 & .64 & .78 & .69 & .66 & .55 & .41 & n/a & .64 \\
\hline Mean & 4.77 & 5.18 & 5.19 & 4.46 & 4.61 & 2.52 & 4.36 & 3.28 & 250.02 & 4.39 \\
\hline$\underline{S D}$ & .84 & 1.22 & .93 & 1.53 & 1.24 & 1.02 & 1.41 & 1.16 & 396.41 & 1.24 \\
\hline
\end{tabular}

$* p<.05$.

$* * p<.01$.

CR: Composite reliability.

AVE: Average variance extracted.

SD: Standard deviation.

${ }^{\text {a }}$ Figures on the diagonal are square roots of AVE, which indicate discriminant validity when greater than the individual correlations.

n/a: Not applicable (single measure latent variable). 


\section{Dependent Variables}

\begin{tabular}{|c|c|c|c|c|c|}
\hline \multirow[b]{2}{*}{ Variables } & \multirow[b]{2}{*}{ Hypotheses } & \multicolumn{2}{|c|}{ DV1: Radical Innovation } & \multicolumn{2}{|c|}{ DV 2: Financial Performanc } \\
\hline & & $\begin{array}{l}\text { Standardized } \\
\text { path estimate }\end{array}$ & $t$-value ${ }^{b}$ & $\begin{array}{l}\text { Standardized } \\
\text { path estimate }\end{array}$ & $t$-value ${ }^{\mathrm{b}}$ \\
\hline \multicolumn{6}{|l|}{ Direct Effects } \\
\hline Market Knowledge & & -.09 & $-1.84 *$ & & \\
\hline Market knowledge resources 2 & $\mathrm{H}_{1}(\Omega)$ & -.14 & -.95 & & \\
\hline Reputational resources & $\mathrm{H}_{2}(-)$ & -.22 & $-1.43^{\dagger}$ & & \\
\hline Relational resources & $\mathrm{H}_{3}(+)$ & .45 & $3.27 * *$ & & \\
\hline \multicolumn{6}{|l|}{ Interaction Effects } \\
\hline Radical innovation & & & & .06 & .40 \\
\hline $\begin{array}{l}\text { Radical innovation } \times \text { Market } \\
\text { knowledge resources }\end{array}$ & $\mathrm{H}_{4}(-)$ & & & -.63 & $-1.74 *$ \\
\hline \multicolumn{6}{|l|}{ Radical innovation $\times$} \\
\hline Reputational resources & $\mathrm{H}_{5}(+)$ & & & .28 & $1.87 *$ \\
\hline \multicolumn{5}{|l|}{ Radical innovation $\times$} & $1.87^{*}$ \\
\hline \multicolumn{6}{|l|}{ Controls } \\
\hline Competitive turbulence & & .02 & .19 & & \\
\hline Centralization & & -.04 & -.39 & & \\
\hline Technological resources & & .42 & $5.96 * *$ & & \\
\hline Financial resources & & .34 & $5.82 * *$ & -.01 & -.06 \\
\hline Size & & .27 & $2.00 *$ & -.04 & -.25 \\
\hline Market knowledge resources & & & & .07 & .81 \\
\hline Reputational resources & & & & .70 & $3.02 * *$ \\
\hline Relational resources & & & & -.14 & -.69 \\
\hline \multicolumn{6}{|l|}{ Squared Multiple Correlations } \\
\hline For Reduced Form & & .57 & & .3 & \\
\hline
\end{tabular}

\section{Figure 1. Conceptual Framework}

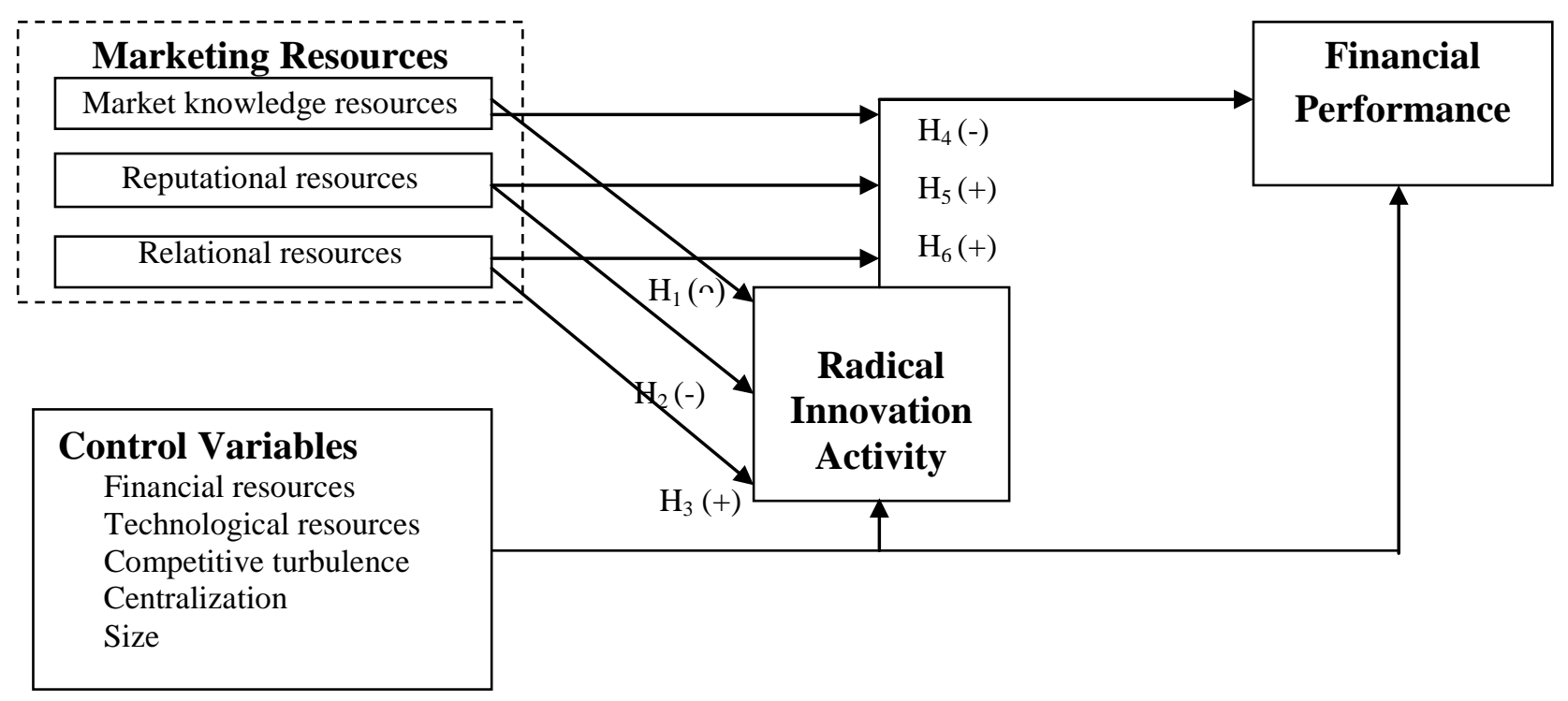




\section{Endnotes}

i Bower and Christensen (1995) defined disruptive technologies as initially performing far worse along dimensions important to existing customers of a firm. By applying a marketing resources perspective to radical innovation activity, and focusing this through the lens of the attention-based view, it would not be appropriate to define radical innovation in the pure disruptive sense put forward by Bower and Christensen (1995) because any such radical innovation that performed poorly in idea, concept, prototype, or final product terms against the existing product would be blocked by boundedly rational managers (Ocasio 1997). Thus the work of Chandy and Tellis $(1998,2000)$ and colleagues is followed in defining radical innovation as fulfilling key customer requirements much better than the established technology and not worse than it.

${ }^{\text {ii }}$ Of these firms, 5 firms have more than 1000 employees 11 firms between 400 and 1000 employees, 67 firms between 100 and 400 employees, and 37 firms between 50 and 100 employees. Moreover 24 firms are active in fine chemicals (SIC 28), 39 firms in industrial machinery and equipment (SIC 35) 18 firms in electric and electronic equipment (SIC36) 12 firms in transportation (SIC 37), and 17 firms in instruments (SIC 38).

iii Informants reported long experience in their current position (mean $=8.18$ years, s.d. $=7.37$ years); high levels of importance to their job positions for tasks related to product innovation (mean $=5.83$, s.d. $=1.15$ on a 7 -pt scale), market intelligence (mean $=6.09$, s.d. $=.93$ ), branding (mean $=4.54$, s.d. $=1.85)$, and relationships with supply chain partners (mean $=6.05$, s.d. $=1.15)$; and they reported high levels of involvement with product innovation (mean = 5.17, s.d.=1.65), market intelligence $($ mean $=5.92$, s.d. $=1.35)$, branding $($ mean $=4.65$, s.d. $=1.93)$, and relationships with supply chain partners (mean $=5.21$, s.d. $=1.71$ ).

${ }^{\text {iv }}$ Radical innovations mentioned by our respondents included LCD and plasma TV, LED technologies, ADSL VOIP router modem, new color printer for offices, ground proximity warning systems for aircrafts, detection and signal processing for radar signals, introduction of tetra radios \& accessories, robots for space exploration, energy efficiency monitoring systems, gas flow metering equipment, lower $\mathrm{CO} 2$ emission engines, composite drag braces for vehicles, low emission combustion systems for industrial gas turbines, sigma method for designing and building ships, RFID technology systems, drug coated stents, resurfacing hip implants.

${ }^{v}$ CMV-adjusted CFA Model 1: $\chi^{2}$ (d.f.) $=242.79(160) ; p=.00 ; \chi^{2} /$ d.f. $=1.51 ;$ RMSEA = .08; CFI = .97; NNFI = $.96 ;$ IFI $=.97$.

${ }^{\text {vi }}$ CMV-adjusted CFA Model 2: $\chi^{2}$ (d.f.) $=99.36(68) ; p=.01 ; \chi^{2} /$ d.f. $=1.46 ;$ RMSEA $=.07 ;$ CFI $=.92 ;$ NNFI $=.89$; IFI $=.92$. 